\title{
Victimological prevention of violent criminality against helpless victims: general theoretical analysis
}

\author{
Ilmira Rifkatyevna Shikula ${ }^{1 *}$, Svetlana Anatolyevna Afanasyeva ${ }^{2}$, Yuliya Vyacheslavovna \\ Gavrilova $^{2}$, Rita Surenovna Danelyan ${ }^{3}$, and Sergey Vladimirovich Danelyan ${ }^{3}$ \\ ${ }^{1}$ Law School of the Institute of Law and Management, State Autonomous Educational Institution of \\ Higher Education, Moscow City Pedagogical University, Department of State Legal Disciplines; \\ Autonomous Noncommercial Organization of Higher Education Moscow International University, \\ Department of Criminal Law and Process, Moscow, Russia \\ ${ }^{2}$ Law School of the Institute of Law and Management, State Autonomous Educational Institution of \\ Higher Education, Moscow City Pedagogical University, Department of State Legal Disciplines, \\ Moscow, Russia \\ ${ }^{3}$ Law School of the Institute of Law and Management, State Autonomous Educational Institution of \\ Higher Education, Moscow City Pedagogical University, Department of Criminal Legal Disciplines, \\ Moscow, Russia
}

\begin{abstract}
The article discusses primary trends in prevention of violent criminality against rights and freedoms of helpless victims. Based on general theoretical methods of analysis and synthesis, generalization, citation, axiomatic methods, the authors come to a conclusion that to affect victimization processes of the most vulnerable part of population, it is required to create an informational basis covering a set of people acknowledged as helpless due to a disease or disability, of senior or minor age, as well as persons living in difficult families as potentially being at risk to be subject to criminal actions. In this connection, the authors believe that in the area of victomolgical protection of vulnerable citizens at the current stage, it is required to improve efficiency of law-enforcement activity in terms of prevention of breaches of social rights of this category of citizens, including rights for victimological rehabilitation, which requires improvement of legal mechanisms envisaging a system of measures for victimological prevention of violent criminality. Maximum possible promulgation of information concerning the number of registered crimes towards helpless victims is a relevant and vital need. First of all, this signifies attention exerted by law-enforcement authorities towards the most vulnerable part of population. Secondly, this forms an irreconcilable attitude of the society towards persons committing such crimes. Thirdly, this creates a basis to improve awareness of helpless persons relative to risks occurring due to their condition and to minimize the distrust syndrome occurring because of a stereotype concerning no possibility or desire of lawenforcement authorities to help them. Moreover, general public will have a complete and objective (rather than fragmentary) understanding covering the entire range of illegal actions committed against such victims.
\end{abstract}

\footnotetext{
* Corresponding author: ila.vnii@mail.ru
} 
Keywords: victim rights and freedoms, incapacitated and disabled persons, domestic violence, economic and social rehabilitation

\section{Introduction}

In the legal doctrine of Russia and foreign countries, the problems of criminal legal protection of helpless victim rights and freedoms has not been substantially transformed in relation to general principles and criminalization of socially dangerous actions.

Russian and foreign criminal legal and criminological researches pay insufficient attention to genesis of a helpless condition so it obtains a limited or, on the contrary, expanded understanding. While the domestic legal doctrine uses age, somatic or psychic specifics, foreign researches pay a higher attention to the background of primary victimization with a predictive evaluation of perspectives of repeated victimization. Crimes against helpless victim rights and freedoms represent a part of violent criminality including primary and repeated victimization of persons characterized by age, somatic or psychic helplessness, namely, a number of intentional illegal actions intended against primary natural personal rights and freedoms: life, health, freedom. To improve efficiency of victimological prevention of crimes against helpless victims, the authors propose to publish generalized information concerning qualitative characteristics of victims in open sources.

\section{Methods}

The authors of the research used the following general theoretical methods as a methodological basis. The analysis method as the primary method of scientific understanding and cognition suggesting studies of the origin, providing and implementing mental analysis of the ontologically integral aggregate into a sum of ontologically individual units. This method is used during applied analytical studies similar to this research. Scientific synthesis is based on legal understanding and legal interpretation of the problems researched by the authors. The axiomatic method is used by the authors as one of the ways of deductive building of theories. The paper also uses the citation method as a way of reasoning, illustration and information transfer. The generalization method in its particular manifestation as a method of systematization is also used by the authors in this study.

\section{Results}

Crime prevention is one of the relevant problems in countering criminality provided that complete neutralization of violent criminality is objectively impossible, and prevention measures allowing for reduction of victimization risks for helpless persons and improvement of possible identification of upcoming or potentially possible crimes against them become very important since victomoligical prevention of criminality is closely related with criminological measurement of its condition and dynamics, and it is required to pay attention to the fact that objective information on actual indicators characterizing the statistical situation and primary parameters of illegal activity against helpless victims is hard to access, and statistic accounting of information concerning victims of illegal actions has negative deformations. On the one hand, information about victims is reflected in two statistical cards since 2006 - Form No. 5 and Form No. 1 provided that it contains gender and age characteristics of persons suffered from criminal actions, and it is insufficient to calculate the level of population victimization. 
Considering that accounting for moral-psychological role and other subjective qualities of a victim is hardly possible, it can be suggested that including those victim attributes [1] that are reflected in criminal legal norms (pregnancy, helplessness, addiction) into the list of accounted information is quite possible. Moreover, upon the completion of criminal investigation, this information must not be re-collected additionally, since it is available in the bill of indictment that contains the clause, part of the article and article of the Special Part of the Russian Federation Criminal Code in accordance with which the actions of the accused are qualified. Currently, the issue of expanded accounting of information on personalities of victims has already been a subject of scientific studies [2], and the resulted ideas concerning its future perspectives can be supported.

Forming a database for the real number of registered crimes against helpless victims can be a foundation used to build their prevention system. It should be noted that crime prevention in the modern foreign doctrine is considered through the lens ensuring safety [3]. This is a significant difference from the Russian criminology theory and law-making practice where crime prevention is still a part of countering. Crime countering includes prevention of future crimes and constraint of undergoing socially dangerous acts [4].

In terms of improving security of helpless persons, the right for physical safety as a number of integral benefits belonging to each person by nature becomes very important, so the state must implement a preventative strategy minimizing opportunities of crimes against victims in order to guarantee physical safety of helpless persons.

Criminological science of foreign countries provides a thesis concerning the need to protect a potential victim, this has become a purpose of crime prevention in many states in the modern period $[5,6]$. Therefore, collective experience of crime victims has become a subject of both psychological and criminological researches. This caused stiffening of rules of punishment assignment especially for violent and lucrative violent crimes. However, there is still no balance of protected values that could be a basis to protect interests of some people without impairment of rights of other people (indirectly, preventative restrictions may cover interests of law-abiding citizens, for example, family members of convicts), and prioritization accomplished in the criminal practice has become a subject of scientific criticism [7]. It is believed that this experience must be taken into account in improvement of the Russian crime prevention legislation.

In other words, a database must be developed to include persons acknowledged as helpless due to a disease or incapacity, of senior or minor age, as well as persons living in difficult families as those potentially at risk of being subject to criminal activities. An individual segment of this database must be accounting for information about victims of violent crimes. It is intended to form an array of data on the number of people that are subject to the maximum risk of victimization, on conditions of their life and existing kinship and other social relations. A preventative significance of this database lies in the fact that in case of committing a crime against a person included in the database, law-enforcement authorities can have information about possible suspects. Moreover, helpless persons can be provided with social services and target support. In general, social support of helpless persons seems to be necessary in the field of criminal legal relations and beyond it [8].

To prevent victimization of helpless people, efficient propaganda of standards of safe communication is required. First of all, this concerns minor and senior persons. All opportunities provided by technological advances can be used for that (social networks, Internet resources, remote communication, hot lines). Participation of charity organizations in the activity is a well-established stereotype widely used in foreign practice [9], but the key role must be played by state and social institutes.

Legislation of some foreign countries provide that persons sentenced for violent crimes must undertake a course of psychological and psychiatric treatment. Doctrinal researches prepared by foreign scientists contain arguments in favor of anger management [10]. There 
are no legal obstacles for borrowing this practice into the Russian legal system: out-patient treatment by a psychiatrist can be combined with execution of the punishment (Articles 97 and 100 of the Russian Federal Criminal Code), and in case of probation, the court may impose such obligations on the subject that will facilitate correction (Part 5, Article 3 Russian Federal Criminal Code). Medical and social help to people not controlling own aggressive manifestations but not suffering from psychic disorders preventing criminal capacity would prevent committing new violent crimes by them [11].

In foreign criminological studies, monitoring of risks faced by most vulnerable categories of persons irrespective of gender is still relevant. An important role in such monitoring is played by divisions of the World Health Organization (WHO) and scientific centers (for example, the Center for Public Health Care at the Liverpool John Moores University in Liverpool, UK). In particular, they have obtained interesting data used thereafter in planning of prevention measures.

In July 2012, an overview of propagation and risk of committing violent crimes showed that disabled children are 3.7 times more frequently become victims of any violence, 3.6 times more frequently become victims of physical violence and 2.9 times more frequently become victims of sexual violence. As for disabled adults, a probability of facing criminal aggression is 1.5 time higher than in health adults [12]. Based on these data, Great Britain implements target prevention of violent crimes which includes law-enforcement authorities, health care facilities municipalities, social organizations and social protection authorities [13]. This approach gives an accurate number of potential victims in the risk group and reveals probable reasons of harm-doers. Moreover, a great role in crime prevention relative to helpless victims is played by post-penitentiary control that suggest social accounting of most dangerous criminals and surveillance over them both in Russia and in the foreign countries. Its results are deemed sufficient by scientists to substantially prevent repeated violent crime $[14,15]$.

\section{Conclusion}

1. To optimize victimological prevention of crimes against helpless victims, it is required to improve informational transparency concerning the status and dynamics of this type of criminality. In this connection, it is required to publish these data in publicly available sources. This would have an educational role and would allow maintaining objective understanding in the society concerning the law-enforcement system capability to protect most vulnerable groups of population.

2. In addition to existing surveillance tools in the Russian law that have been approved by domestic criminologists, it seems reasonable to implement special prevention accounting covering subjects held criminally liable for committing crimes towards helpless victims. Registration of such persons whose criminal prosecution was completed due to settlement with the injured party will help overcoming the illusion of impunity which may result in more severe crimes.

3. In the foreign criminological doctrine and legislation, the primary standard of protection of helpless persons has become preventive provision of security. However, the balance of values and interests has not yet found an optimal manifestation, which allows applying a wide list of restrictions not aligned with natural human rights to a significant scope of persons. 


\section{References}

1. A.L. Repetskaya, Viktimologicheskaya kharakteristika regionalnoi prestupnosti i ee preduprezhdenie [Victomological Characteristic of Regional Criminality and Its Prevention] (Academia, Moscow, 2009)

2. N.V. Akhmedshina, TSU J. of Law, 334, 88-90 (2010)

3. H. Carvalho, The preventive turn in criminal law (Oxford University Press, Oxford, 2017)

4. R.V. Zhubrin, Teoreticheskie osnovy preduprezhdeniya prestupnosti na sovremennom etape razvitiya rossiiskogo obshchestva [Theoretical Basics of Crime Prevention at the Modern Stage of Russian Society Development] (Prospekt, Moscow, 2016).

5. M.D. Dubber, Victims in the war of crime: the use and abuse the victims' rights (NYU 11. Press, New York, 2006)

6. L. Sebba, Victim-driven criminalization. Regulating deviance: the redirection of criminalization and the futures of criminal law (Hart Publishing, Oxford, 2009)

7. H. Carvalho, A. Chamberlen, Punishment and Soc. 2, 227 (2018). https://doi.org/10.1177/1462474517699814

8. R.S. Danelyan, Rus. Judge, 2, 40-43 (2012)

9. J.T. Mayne, K.T. Ambrose, J. of Clinical Psy. 55, 353-363 (1999). https://doi.org/10.1002/(SICI)1097-4679(199903)55:3<353::AID-JCLP7>3.0.CO;2-B

10. E.S. Buzawa, C.G. Buzawa, E. Stark, Responding to the domestic violence: the integration of criminal justice and human services (SAGE Publications, London, 2011)

11. I.R. Shikula, Ugolovno-pravovaya okhrana prav i svobod poterpevshego, nakhodyashchegosya $\mathrm{v}$ bespomoshchnom sostoyanii, ot nasil'stvennykh prestuplenii: problemy teorii i praktiki [Criminal Legal Protection of Rights and Freedoms of a Helpless Victims Against Violent Crimes: Problems of Theory and Practice] (YURLITINFORM, Moscow, 2020)

12. World Health Organization. Violence against adults and children with disability. Accessed on: March 16, 2021. [Online]. Available: http://www.who.int/disabilities/violence/en/

13. Gov.UK. The Serious Violence Strategy. Accessed on: March 16, 2021. [Online]. Available: https://www.gov.uk/government/publications/serious-violence-strategy

14. D.N. Sergeyev, Herald of Omsk University. Law Ser. 1, 203-209 (2016)

15. A.A. Shanina, Penitentiary Sc. 1, 38-43 (2017)

16. A.L. Gurinskaya, Anglo-amerikanskaya model preduprezhdeniya prestupnosti [AngloAmerican Model of Crime Prevention], Doctoral dissertation, 111-113 (Saint Petersburg, 2018) 